\title{
Enhancing Farmers' Income by Cultivating Summer Green Gram
}

\author{
P. S. Sidhu* and G. S. Dhillon \\ Punjab Agricultural University, Ludhiana \\ Krishi Vigyan Kendra, Bathinda \\ *Corresponding author
}

\section{A B S T R A C T}

\begin{tabular}{|c|}
\hline Keywords \\
\hline $\begin{array}{l}\text { Front line } \\
\text { demonstrations, } \\
\text { Summer green } \\
\text { gram, Extension } \\
\text { gap, Technology } \\
\text { gap, Technology } \\
\text { index, Net returns }\end{array}$ \\
\hline Article Info \\
\hline $\begin{array}{l}\text { Accepted: } \\
15 \text { February } 2020 \\
\text { Available Online: } \\
10 \text { March } 2020\end{array}$ \\
\hline
\end{tabular}

For doubling the income of the farmers, the central as well as the state governments are focusing on the possible alternatives. The various aspects such as crop diversification, crop intensification and cropping pattern can enhance the income of the farmers. Under crop intensification, the front line demonstrations on summer green gram were conducted at farmers' field in Bathinda district to increase the income of the farmers and the productivity during the years 2016-17, 2017-18 and 2018-19. The data was recorded under both the front line demonstrations as well as under farmer practices and compared with each other. The data was pooled for three years and it was observed on an average yield of the crop. The average grain yield in the tune of $10.94 \mathrm{q} / \mathrm{ha}$ was observed under demonstrations as compared to farmer practices $(9.96 \mathrm{q} / \mathrm{ha})$. The extension gap, technology gap and technology index were calculated for three years were 0.98 q/ha, 0.39 q/ha and $3.44 \%$ respectively. The average higher net returns Rs. $37577 /$ - and highest benefit: cost ratio 1.26 was observed. The average increase in net returns $(15.7 \%)$ was highest under front line demonstrations over farmer practices.

\section{Introduction}

Pulses play a pivotal role in Indian agriculture. In India, pulses are grown over an area of 23.4 million hectares with a total production of 18.4 million tones (Anonymous, 2019). Pulses which have a key role to play in agriculture and society for various factors like their nutritive value, predominantly vegetarian diet, potential to improve soil fertility, low resource and water requirement, etc. Pulses and its products are a rich source of essential nutrients like protein, minerals and vitamins. Pulses can easily meet the protein requirement of a vegetarian diet. As diet of Indians is deficient in respect of quality and quantity of protein, mixing of pulses grains with other cereals enhances the nutritive value of the food. Out of pulses, green gram is an important short duration pulse crop in India. It contains $24.7 \%$ protein, $0.5 \%$ fat, $0.9 \%$ fibre, $57.6 \%$ carbohydrates and $3.7 \%$ ash (Choudhary et al., 2010). Green gram covers the annual world production of 
about an area of 5.5 million hectares. In India, it ranks third after bengal gram and red gram in area, production and productivity (Shishir et al., 2017).

Punjab has played a vital role as far as the production of pulses is concerned. Pulses are mainly grown in the state in Rabi, Kharif \& Zaid (summer). In Punjab, green gram crop is grown over an area of 3.5 thousands hectares with a total production of 3.0 thousand tonnes and an average yield of $845 \mathrm{~kg}$ per hectares and out of which in Bathinda district of Punjab, green gram was grown over an area of 0.3 thousands hectares with a total production of 0.2 thousand tonnes and an average yield of $895 \mathrm{~kg}$ per hectares in the year 2017-18 (Anonymous, 2019).

Summer Green gram can ideally be grown in irrigated tracts of Punjab as catch -cum cash crop for diversifying rice-wheat system. Success in summer cultivation has not only increased the green gram production but also helped in defeating malnutrition, crop diversification, sustaining agricultural production and increasing house-hold income of poor farmers of Punjab.

Cotton-wheat rotation was the traditional cropping system of Bathinda district of Punjab. But due to problems of insect-pests on cotton crop and increasing number of electric pumps in the state, which is due to free farm electricity, the area under cotton decreased and it is replaced by rice. The summer moong crop can be successfully grown after harvest of potato or fodder crop as the recommended sowing time of the crop is $20^{\text {th }}$ March to $10^{\text {th }}$ April. The productivity of summer moong is not sufficient on account of several causes like unavailability of quality seeds of improved varieties well in time and poor crop management practices due to unawareness and non-adoption of recommended production \& plant protection technologies. Therefore, it becomes necessary to demonstrate the high yielding varieties, follow recommended sowing time, resistant to biotic and abiotic stresses and other production technologies which the farmers generally do not adopt. Keeping above points in view, Front line demonstrations were conducted on summer moong (var. SML 832) by Krishi Vigyan Kendra. The main objective of the study was to boost up the productivity of summer green gram by use of recommended high yielding summer green gram variety with full recommended package of practices.

\section{Materials and Methods}

The front line demonstrations on summer green gram were conducted at farmers' field in Bathinda district to increase the income of the farmers and the productivity of the crop during the years 2016 to 2018. Bathinda is in the northwestern region of India and is a part of the Indo-Gangetic alluvial plains. The geopgraphic co-ordinates of Bathinda are $30^{\circ} 12$ ' $10.82^{\prime} \mathrm{N}$ (Latitude) and and $74^{\circ}$ 56 ' 21.22" E (Longitude). It has an average elevation of 201 metres. It is situated in Trans-Gangetic Plain Region. Bathinda's climate corresponds to semi-arid region with high variation between summer and winter temperatures. The soils of the district vary from sandy to clay loam in texture which is low to medium in organic carbon (0.3 to $0.6 \%$, available phosphorus (12- $18 \mathrm{~kg} / \mathrm{ha})$ and medium to high in potash (125-185).

Each demonstration was conducted in an area of 0.4 ha and the critical inputs were applied as per the package of practices for Rabi crops recommended by the Punjab Agricultural University, Ludhiana. The quality seed of summer moong variety SML 832 was used for conducting FLD and treated with biofertilizer during all the years of the study (Kaur et al., 2010). The sowing operation was 
carried out from mid March to first week of April under assured irrigated conditions and harvested during first fortnight of June (Table 1). The demonstrations at farmers' fields were regularly monitored by scientists of Krishi Vigyan Kendra, Bathinda from sowing to harvesting. The grain yield of demonstration crop was recorded and analyzed. The obtained data was pooled by using different statistical tools for 2016-17, 2017-18 and 2018-19 years. The extension gap, technology gap and the technology index were worked out as per formulae given by the Yadav et al., (2004).

(EG) Extension gap= Demonstration yieldFarmers yield

(TG) Technology gap = Potential yield Demonstration yield

(TI) Technology index=

$\underline{\text { (Potential yield - Demonstration yield) X } 100}$ Potential yield

\section{Results and Discussion}

The main focus of the study was to popularize summer moong \& implementation of full package of practices. The major difference was observed between the practices followed under front line demonstrations and farmer practices such as use of variety, seed rate, seed treatment, sowing time, weed management, nutrient management and integrated pest management. The results in table (1) shows the recommended package of practices was applied under conductance of front line demonstrations as compared with farmer practices.

The farmers used the un-recommended desi/local variety of summer green gram with high seed rate then applied no seed treatment, un-recommended sowing time, no use of herbicides \& pesticides and applied improper dose/time of fertilizer as compared with front line demonstrations. These differences cause the high yield of summer green gram under front line demonstrations. Similar findings have also been observed by Yadav et al., (2007).

\section{Yield}

Grain yield is the net result of various agronomic factors/inputs influencing growth and yield attributing characters during the life cycle of the crop. The efficiency of different factors was judged mainly by their contribution to the economic yield. It is evident from yield and gap analysis between demonstrations and farmer practices presented in table (2). The average grain yield $10.94 \mathrm{q} / \mathrm{ha}$ was recorded under demonstrations as compared to farmer practices (9.96 q/ha) during 2016-17 to 201819. Similarly, yield enhancement in different crops under front line demonstrations were recorded by Lalit et al., (2015), Mishera et al., (2009) and Dhaka et al., (2010). The highest increase in yield was observed $5.3 \%, 11.6 \%$ and $15.3 \%$ during 2016-17, 2017-18 and 2018-19 respectively. Figure-2 depicted every year increase in yield under front line demonstrations might be due to follow up of recommended agronomic practices and regularly field visits by KVK scientists. The farmers who were ignorant from recommended agronomic practices resulted in decrease of grain yield.

\section{Gap analysis}

The gap analysis of frontline demonstrations depicted in figure-1 during 2016-17, 2017-18 and 2018-19 shows a positive variation under frontline demonstrations as compared with farmer practices.

\section{Extension gap}

An extension gap between front line demonstrations and farmer practices was 
calculated through formula which ranges to $0.52 \mathrm{q} / \mathrm{ha}, 0.90 \mathrm{q} / \mathrm{ha}$ and $1.52 \mathrm{q} / \mathrm{ha}$ during 2016-17, 2017-18 and 2018-19 respectively. An average extension gap $0.98 \mathrm{q} / \mathrm{ha}$ was evaluated from data presented in table (2). The gap observed was might be due to the better management of frontline demonstrations from sowing to harvesting as compared with farmer practices.

\section{Technology gap}

The technology gap shows the difference between potential yields over demonstration yield of the technology. The technology gap was calculated from recorded data in table (2). The average potential yield of the summer green gram variety is $11.33 \mathrm{q} / \mathrm{ha}$ and average technology gap $0.39 \mathrm{q} / \mathrm{ha}$ was recorded from 2016-17 to 2018-19. The highest range of technology gap $0.93 \mathrm{q} / \mathrm{ha}$ was found during 2016-17 as compared with 2017-18 (0.15 q/ha) and 2018-19 (0.08). This gap was observed due to the direct supervision of KVK scientists at demo fields from sowing to harvesting. Similar results were found by Dalip Singh (2017), Singh and Chauhan (2010), Meena and Singh (2014).

\section{Technology index}

Technology index represents the variability of recommended technology used for conducting demonstrations at farmer's field. The calculated technology index (table-2) for front line demonstrations during the years 2016-17, 2017-18 and 2018-19 were in accordance to technology gap.. The lower value of technology index $(0.69 \%)$ during the year 2018-19 indicates the more feasibility of followed technology, it means proven for those areas while conducting FLDs on summer green gram. The lower is the value of technology index, the more is the feasibility of technology demonstrated (Sagar and Chandra, 2004). The average value of technology index (3.44\%) observed reflects the recommended technology for transferring to farmers and sufficient extension services for transfer of technology.

Table.1 The practices followed under FLDs and farmers practices

\begin{tabular}{|l|c|c|}
\hline \multicolumn{1}{|c|}{ Particulars } & Demonstration practices & Farmers practices \\
\hline Variety & SML-832 & Local /private \\
\hline Seed rate (kg/ha) & $37.5 / 30$ & 45 \\
\hline $\begin{array}{l}\text { Seed treatment with } \\
\text { biofertilizer }\end{array}$ & Rhizobium culture & No seed treatment \\
\hline Sowing time & 20 March to 10, April & Second fortnight of April \\
\hline Weed management & Stomp 30EC @ 2.5 1/ha & No use of weedicides \\
\hline $\begin{array}{l}\text { Nutrient management } \\
\text { (N:P:K) }\end{array}$ & $12.5: 40: 0$ & $25: 0: 0$ \\
\hline IPM & Rogar 30EC @ 250ml/ha & No use of pesticides \\
\hline
\end{tabular}


Table.2 Yield \& Gap analysis of Front Line Demonstrations

\begin{tabular}{|c|c|c|c|c|c|c|c|c|c|c|}
\hline \multirow[t]{2}{*}{ Year } & \multirow[t]{2}{*}{ Variety } & \multirow{2}{*}{$\begin{array}{c}\text { Potential } \\
\text { yield } \\
\text { (q/ha) }\end{array}$} & \multirow{2}{*}{$\begin{array}{c}\text { No. of } \\
\text { demons. }\end{array}$} & \multirow{2}{*}{$\begin{array}{c}\text { Area } \\
\text { (ha) }\end{array}$} & \multicolumn{2}{|c|}{ Yiled (q/ha) } & \multirow{2}{*}{$\begin{array}{c}\text { Yield } \\
\text { increase } \\
(\%)\end{array}$} & \multirow{2}{*}{\multicolumn{2}{|c|}{\begin{tabular}{c|c} 
Extension Technology \\
gap \\
(q/ha)
\end{tabular}}} & \multirow{2}{*}{$\begin{array}{l}\text { Technology } \\
\text { index }(\%)\end{array}$} \\
\hline & & & & & Demo & $\begin{array}{l}\text { Farmer } \\
\text { practice }\end{array}$ & & & & \\
\hline 2016-17 & SML-668 & 11.25 & 75 & 30 & 10.32 & 9.8 & 5.3 & 0.52 & & 8.26 \\
\hline 2017 & SML- 6 & & 75 & 30 & & & 11 & 0.9 & & \\
\hline 2018-19 & SML-832 & & 37 & & 11. & & 15 & & & \\
\hline & Avera & 11.33 & 62.33 & 24.93 & 10.94 & 9.96 & 10.73 & 0.98 & 0.39 & 3.44 \\
\hline
\end{tabular}

Figure.1 Variation in gap analysis of frontline demonstrations on summer moong during experimental years

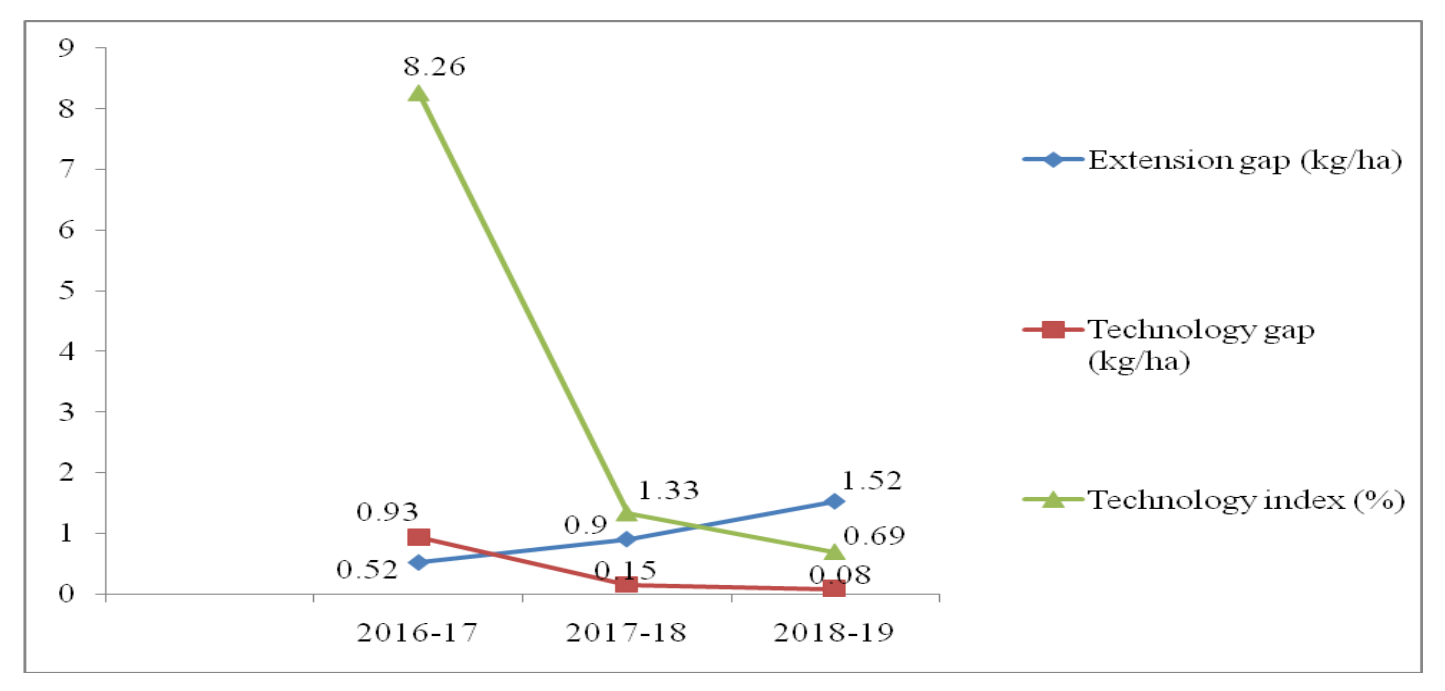

Figure.2 Variation in yield of summer moong under FLDs as compared with farmer practice

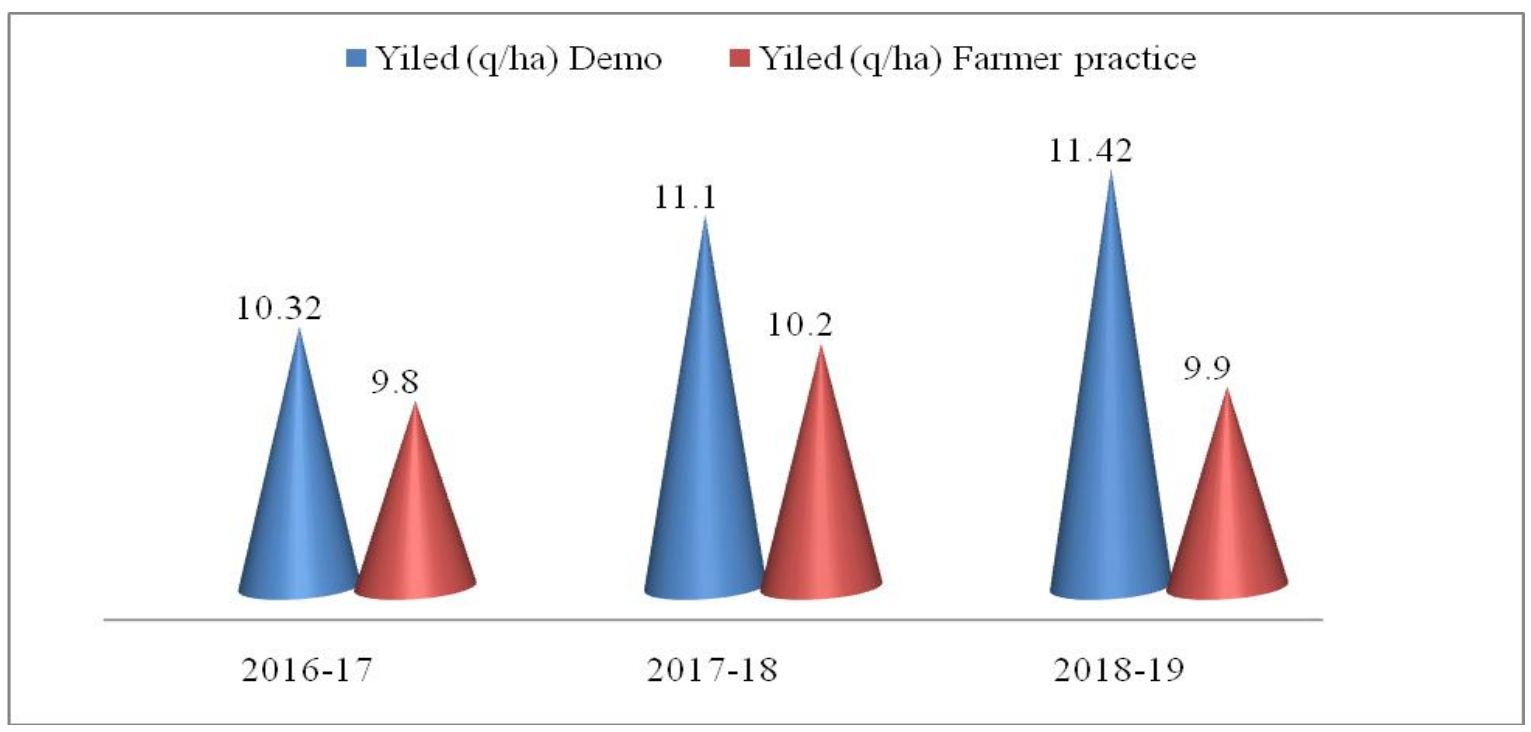


Table.3 Economic analysis of front line demonstrations

\begin{tabular}{|c|c|c|c|c|c|c|c|c|c|c|}
\hline \multirow[t]{3}{*}{ Year } & \multirow{3}{*}{$\begin{array}{c}\text { MSP } \\
\text { (Rs./q) }\end{array}$} & \multicolumn{8}{|c|}{ Economics (Rs./ha) } & \multirow{3}{*}{$\begin{array}{c}\text { Net returns } \\
\text { increase } \\
(\%)\end{array}$} \\
\hline & & \multicolumn{4}{|c|}{ Demo } & \multicolumn{4}{|c|}{$\begin{array}{l}\text { Check } \\
\end{array}$} & \\
\hline & & $\begin{array}{c}\text { Gross } \\
\text { Cost } \\
\text { (Rs/ ha) }\end{array}$ & $\begin{array}{c}\text { Gross } \\
\text { return } \\
\text { (Rs/ ha) }\end{array}$ & $\begin{array}{c}\text { Net } \\
\text { Return } \\
\text { (Rs/ha) }\end{array}$ & $\begin{array}{l}\mathrm{B}: \mathrm{C} \\
\text { ratio }\end{array}$ & $\begin{array}{c}\text { Gross Cost } \\
\text { (Rs/ ha) }\end{array}$ & $\begin{array}{c}\text { Gross } \\
\text { return } \\
\text { (Rs/ ha) }\end{array}$ & $\begin{array}{c}\text { Net Return } \\
\text { (Rs/ha) }\end{array}$ & $\begin{array}{l}\text { B:C } \\
\text { ratio }\end{array}$ & \\
\hline 2016-17 & 5650 & 28682 & 58308 & 29626 & 1.03 & 27755 & 55370 & 27975 & 1.00 & 5.90 \\
\hline 2017-18 & 5775 & 29900 & 64102.5 & 34202.5 & 1.14 & 28880 & 58905 & 30025 & 1.03 & 13.9 \\
\hline 2018-19 & 6975 & 30752 & 79654.5 & 48902.5 & 1.59 & 29645 & 69052.5 & 39407.5 & 1.32 & 24.0 \\
\hline Avg. & 6133.33 & 29778 & 67355 & 37577 & 1.26 & 28760 & 61109.16 & 32469.16 & 1.12 & 15.7 \\
\hline
\end{tabular}

\section{Economics of front line demonstrations}

It is meaningful to understand the economical measures of the demonstrated technology as compared to the farmer practices. All the input-output cost data were recorded during the experimental years and analyzed. The comparative analysis data are presented in table 3. Economic returns and minimum support price (MSP) varied during the study period. The data revealed that highest gross returns (Rs. 79654.5/-) was observed during 2018-19 due to higher grain produce per hectare $(11.42 \mathrm{q} / \mathrm{ha})$ under front line demonstrations then sold at MSP rates in the market. The average gross cost (Rs. 29778/-) of front line demonstrations was recorded higher as compared with farmer practice gross cost (Rs. 28760/-). This might be due to the recommended seed treatment; used herbicides for weed management and integrated pest management applied under front line demonstrations. The average higher net returns (Rs. 37577/-) was recorded under demonstrations after excluding the gross cost from gross returns as compared to farmer practices. The benefit: cost ratio was calculated from net returns over gross cost. The highest average (1.26) benefit: cost ratio was observed during 2016-17 to 2018-19 under demonstrations as compared with farmer practices. The highest increase (24.0\%) in net returns during 2018-19 was due to the highest grain yield and MSP during the current year. The average increase in net returns $(15.7 \%)$ was highest under front line demonstrations over farmer practices.

The highest gross returns, net returns and benefit: cost ratio were obtained under frontline demonstrations could be due to followed recommended package of practices for summer green gram, timely operations and time to time monitoring of demonstrations field by scientists. The similar findings were observed by Pradeep et al., (2015) and Singh et al., (2012).

From the above study, it is concluded that the front line demonstrations increased the efficiency to boost up the overall productivity of summer green gram. The improved and recommended agronomic practices applied under front line demonstrations reduced the technology gap. The highest gross returns, net returns and benefit: cost ratio were obtained under frontline demonstrations which could be due to follow up of recommended package of practices for summer green gram, timely operations and regularly monitoring of demonstrations fields by scientists. The front line demonstrations create the awareness among the farmers and helped in dissemination of the technology. It also reduces the gap between farmers and scientists and built up the confidence between them. 


\section{References}

Anonymous (2019). Packages of practices for field crops during Rabi. Punjab Agricultural University, Ludhiana, Punjab, India.

Anonymous (2019). India pulses and grain association. Pulses sector in India. http://ipga.co.in/pulses-grown-inindian-region/.

Chudhary R, Sandhu AC, Gagiya KM (2010). Effect of fertility levels and fertilizers on growth, yield and economics of Summer green gram (Vigna radiate $\mathrm{L}$ Wilczek). Haryana Journal of Agronomy. 26:41-44.

Dhaka, B.L., Meena, B.S. and Suwalka, R.L. (2010). Popularization of Improved. Maize production technology through front line demonstrations in south eastern Rajasthan. J. Agri. Sci., 1(1): $39-42$.

Dilip Singh (2017). Impact of Front Line Demonstrations on the Yield and Economics of Tomato in Bharatpur District of Eastern Rajasthan. Int.J.Curr.Microbiol.App.Sci. 6(6): 1556- 1561.

Kaur, Paramjit, A Kaur, B Kaur and K Singh (2014). Performance of frontline demonstrations on summer moong in Jalandhar district. J. Krishi Vigyan 2014, 3(1) : 58-61

Kumar, Shishir and Wilson Kispotta (2017). Impact of frontline demonstrations on summer moong through improved technology in Bhadohi district of Uttar Pradesh, India. Plant Archives Vol. 17 No. 1, 2017 pp. 423-426.

Lalit, M. Patil, D. J. Modi, H. M. Vasava and S. R. Gomkale (2015). Evaluation of Front Line emonstration programme on green gram variety Meha (IPM 99 125) in Bharuch district of Gujrat. SR Jr. of Agri. And Vet. Science, 8(9): $01-$
03.

Meena, M.L. and Singh, D. (2014). Impact of On Farm Testing of chickpea production technology in rainfed condition of Rajasthan. Indian Journal of Extension Education, 48: 93-97.

Mishra, D.K., Paliwal, D.K., Tailor, R.S. and Deshwal, A.K. (2009). Impact of front line demonstrations on yield enhancement of potato. Indian Res. J. Ext. Edu., 9(3): 26-28.

Pradip, Pagaria (2015). Role of front line deomonstration on transfer of moong production technologies in Barmer district of Rajasthan. Agriculture Update, 10(3): $245-248$.

Sagar, R.L. and Chandra, G. (2004). Evaluation of Front Line Demonstration on Mustard in Sunderban, West Bengal. Indian Journal of Extension Education, XXXX, (3\&4):96-97.

Singh, B.S. and Chauhan, T.R. (2010). Adoption of mungbean production technology in arid zone of Rajasthan. Indian Research Journal of Extension 10:73-77.

Singh, Jagmohan, B. S. Dhillon, Astha and Parvindar Singh (2012). Front line demonstration. An effective tool for increasing the productivity of summer moong in Amritsar district of Punjab. Asian J. Soil Sci., 7(2) : 315 - 318.

Yadav D B, Kamboj B K and Garg R B (2004). Increasing the productivity and profitability of sunflower through front line demonstrations in irrigated agroecosystem of eastern Haryana. Haryana J. of Agronomy 20 (1\&2): 3335.

Yadav, V. P. S., R. Kumar, A. K. Deshwal, R. S. Raman, B. K. Sharma and S. L. Bhela (2007). Boosting pulse production through frontline demonstration. Indian Res. J. Extn. Edu., 7 (2 and 3). 


\section{How to cite this article:}

Sidhu, P. S. and Dhillon, G. S. 2020. Enhancing Farmers' Income by Cultivating Summer Green Gram. Int.J.Curr.Microbiol.App.Sci. 9(03): 1933-1940. doi: https://doi.org/10.20546/ijcmas.2020.903.225 